\title{
DAMPAK PENGELOLAAN WARISAN BUDAYA SUBAK JATILUWIH SEBAGAI DAYA TARIK WISATA TERHADAP LINGKUNGAN
}

\author{
Dewa Ayu Diyah Sri Widari \\ Akademi Pariwisata Denpasar \\ Email: dewaayusriwidari@gmail.com
}

Received: August 30, 2021 | Accepted: Oct. 25, 2021 | Published: Nov. 5, 2021

Permalink/DOI: 10.53356/diparojs.v2i1.48

\begin{abstract}
ABSTRAK
Pengelolaan Daya Tarik Wisata Jatiluwih yang memanfaatkan subak sebagai daya tarik utama, selain ditujukan untuk memberikan kesejahteraan bagi masyarakat lokal juga diharapkan dapat mempertahankan eksistensi subak sebagai bagian dari Warisan Budaya Dunia. Pengelolaan Daya Tarik Wisata Jatiluwih sebagai bagian dari Warisan Budaya Dunia berkaitan berdampak terhadap aspek lingkungan. Teknik pengumpulan data dengan cara observasi dan wawancara. Teknik wawancara yang digunakan adalah wawancara mendalam (indepth interview) dilakukan dengan Kepala Desa, Bendesa Adat, Pekaseh, Kelian Dusun, Kelian Tempek, Manajemen Operasional Daya Tarik Wisata Jatiluwih. Teknik wawancara terpimpin dilakukan dengan pengusaha pariwisata dan masyarakat. Pengelolaan pariwisata berdampak terhadap penurunan sumber daya air dan pencemaran air, polusi udara yang dapat mempengaruhi kualitas lingkungan. Pembangunan fasilitas pariwisata yang tidak sesuai dengan tata ruang berdampak negatif terhadap lingkungan yaitu hilangnya bentang alam dan tanah pertanian. Pengelolaan daya tarik wisata juga berdampak positif terhadap lingkungan. Kebersihan lingkungan semakin dijaga, terdapat penampungan limbah cair pada usaha-usaha pariwisata. Fasilitas pariwisata dibangun mengikuti bentang alam Desa Jatiluwih yang berundak-undak yang berdampak terhadap penampilan wilayah (visual dan estetika). Masyarakat lokal menjaga kelestarian hutan, binatang yang hidup di sekitar wilayah Desa Jatiluwih juga dijaga kelestariannya. Keberadaan flora dan fauna masih dijaga kelestariannya, dalam awig-awig Subak Jatiluwih mengandung nilai kearifan lokal pelestarian lingkungan biotik. Desa Jatiluwih memiliki beragam mitos yang dipercaya oleh masyarakat, keberadaan mitos ini sangat berperan dalam menjaga kelestarian lingkungan alam.
\end{abstract}

Kata kunci: dampak, pengelolaan, warisan budaya, Subak Jatiluwih, lingkungan

\section{ABSTRACT}

The management of Jatiluwih Tourist Attraction which utilizes subak as the main attraction, in addition to being aimed at providing welfare for local communities is also expected to maintain the existence of subak as part of the World Cultural Heritage. The management of Jatiluwih Tourist Attraction as part of the World Cultural Heritage is related to the impact on environmental aspects. Data collection techniques by observation and interview. The interview technique used is an indepth interview 
conducted with the Head of Village, Bendesa Adat, Pekaseh, Kelian Dusun, Kelian Tempek, Operational Management of Jatiluwih Tourist Attraction. Guided interview techniques are conducted with tourism entrepreneurs and the community. Tourism management has an impact on the decline of water resources and water pollution, air pollution that can affect environmental quality. The construction of tourism facilities that are not in accordance with spatial planning has a negative impact on the environment, namely the loss of landscapes and agricultural land. The management of tourist attractions also has a positive impact on the environment. Environmental cleanliness is increasingly maintained, there are liquid waste reservoirs in tourism businesses. Tourism facilities are built following the landscape of Jatiluwih Village which is procrastinating has an impact on the appearance of the region (visual and aesthetic). Local people maintain the preservation of the forest, animals that live around the Jatiluwih Village area is also maintained. The existence of flora and fauna found is still maintained, in awig-awig Subak Jatiluwih contains the value of local wisdom of biotic environmental preservation. Jatiluwih village has a variety of myths that are believed by the community, the existence of this myth is very instrumental in maintaining the preservation of the natural environment.

Keywords: impacts, management, world heritage, Subak Jatiluwih, environment

\section{PENDAhUluan}

Lanskap Budaya Provinsi Bali sebagai warisan budaya dunia terdiri dari empat situs yang menunjukkan koneksi erat antara komponen alam, religi, budaya dari sistem subak. Keempat situs tersebut adalah Pura Ulun Danu Batur, yang berkedudukan sebagai pura tirta paling utama dan terletak di tepi Danau Batur yang dianggap sebagai sumber utama dari semua mata air dan sungai yang ada di Bali, Lanskap Subak DAS Pakerisan sebagai salah satu sistem subak tertua, Lanskap Subak Catur Angga Batukaru sebagai contoh utama dari arsitektur Bali Klasik, dan Pura Taman Ayun sebagai gambaran perkembangan sistem subak di bawah kerajaan Bali paling besar pada abad ke-19.

Subak Jatiluwih merupakan bagian dari Lanskap Subak Catur Angga Batukaru yang berlokasi di Desa Jatiluwih, Kecamatan Penebel, Kabupaten Tabanan. Desa Jatiluwih memiliki panorama alam yang indah dengan keunikan sawah berundak-undak. Dengan keunikan terasering sawah yang dimiliki, subak yang merupakan organisasi petani pada sawah di Desa Jatiluwih dijadikan sebagai daya tarik wisata utama. Keunikan terasering sawah juga didukung oleh iklim yang relatif sejuk, karena berada pada ketinggian kurang lebih 1,059 meter.

Pengelolaan Daya Tarik Wisata Jatiluwih yang memanfaatkan subak sebagai daya tarik utama, selain ditujukan untuk memberikan kesejahteraan bagi masyarakat lokal juga diharapkan dapat mempertahankan eksistensi subak sebagai bagian dari Warisan Budaya Dunia. Warga Subak Jatiluwih masih mempertahankan sistem tanam padi dengan dua periode tanam yaitu periode penanaman padi lokal dan periode penanaman padi varietas. Disamping itu, upacara yang terkait dengan aktivitas sawah mulai dari mapag toya sampai mantenin tetap dilaksanakan sebagai tradisi budaya dengan kearifan lokalnya. Namun di sisi lain terjadi pergeseran penggunaan sapi ke traktor untuk membajak sawah, serta pemakaian dari pupuk organik ke pupuk anorganik untuk menyuburkan lahan dan tanaman padi.

Pengelolaan Daya Tarik Wisata Jatiluwih sebagai bagian dari Warisan Budaya Dunia berkaitan dengan aspek lingkungan. Potensi lingkungan abiotik yang dimiliki Desa Jatiluwih adalah panorama persawahan, panorama Pura Luhur Besi Kalung, sumber mata air, air 
terjun, air panas, dan sungai. Potensi lingkungan biotik yang dimiliki Desa Jatiluwih yaitu tanaman (kopi, kelapa, nangka, jati, bambu dan tanaman khas daerah pedesaan) dan hewan (menjangan, burung kokokan) masih dijaga kelestariannya. Permasalahan yang dihadapi oleh warga subak antara lain adanya beberapa sumber mata air yang mulai mengalami penurunan karena faktor alam maupun penggunaan air tanah oleh usaha pariwisata di Desa Jatiluwih. Apabila hal ini tidak mendapat penanganan yang yang baik, dapat mempengaruhi aktivitas serta eksistensi dari Subak Jatiluwih.

Faktor lingkungan yang juga berkaitan dengan pengelolaan Daya Tarik Wisata Jatiluwih yaitu banyaknya usaha peternakan ayam yang dimiliki masyarakat setempat. Usaha peternakan dapat meningkatkan pendapatan masyarakat, namun dapat memberi dampak negatif bagi lingkungan. Usaha peternakan ayam menimbulkan bau yang kurang sedap, selain itu limbah yang ditimbulkan dari peternakan belum dikelola dengan baik (Antara dkk., 2017). Banyaknya usaha peternakan ayam dapat mengganggu pengelolaan lingkungan pariwisata di Subak Jatiluwih dan mempengaruhi kesehatan masyarakat.

\section{KAJIAN LITERATUR}

\subsection{Dampak Pariwisata terhadap} Lingkungan

Pengembangan pariwisata dapat menimbulkan dampak terhadap lingkungan. Lingkungan hidup adalah kesatuan ruang dengan semua benda, daya, keadaan, dan makhluk hidup, termasuk manusia dan perilakunya, yang mempengaruhi alam itu sendiri, kelangsungan perikehidupan, dan kesejahteraan manusia serta makhluk hidup lain (Undang-undang Republik Indonesia Nomor 32 Tahun 2009 tentang Perlindungan dan Pengelolaan Lingkungan Hidup).

Permasalahan lingkungan yang mendasar sangat berkaitan dengan populasi manusia, sebab meningkatnya kepadatan penduduk dapat meningkatkan kebutuhan pangan, bahan bakar, pemukiman dan kebutuhan dasar lainnya. Permasalahan lingkungan antara lain disebabkan oleh kerusakan hutan, penurunan keanekaragaman hayati, lahan kritis, erosi, kerusakan Daerah Aliran Sungai (DAS), pencemaran air, pencemaran udara, sampah dan limbah, sanitasi lingkungan, kemiskinan, rendahnya kesadaran dan peran serta masyarakat dalam pengelolaan lingkungan hidup, dan lemahnya penegakan hukum untuk pengelolaan lingkungan hidup (Adnyana dan Suarna, 2007).

Dampak potensial pariwisata terhadap lingkungan alami berdasarkan komponen lingkungan, antara lain (1) flora dan fauna, fenomena dampak negatif yaitu gangguan perkembangbiakan, hilangnya atau kepunahan binatang, perubahan pola migrasi binatang, dan kerusakan vegetasi; (2) polusi, fenomena dampak negatif yaitu polusi air, polusi udara, dan polusi suara; (3) erosi, fenomena dampak negatif yaitu pengikisan permukaan tanah, tanah longsor, dan kerusakan kawasan tepi sungai; (4) sumber daya alam, fenomena dampak negatif yaitu habisnya cadangan air tanah dan air permukaan, dan tingginya kemungkinan kebakaran; dan (5) dampak pemandangan, fenomena dampak negatif yaitu kawasan terbangun yang tampak buruk, dan pemandangan yang kotor (Hartanto, 1997:52).

Dampak positif pengembangan pariwisata terhadap lingkungan antara lain 
perlindungan terhadap lingkungan alam, melestarikan monumen dan bangunan bersejarah, memperbaiki penampilan suatu daerah (visual dan estetika). Pariwisata juga memberi dampak negatif yaitu menimbulkan polusi (udara, air, suara, limbah), hilangnya bentang alam dan tanah pertanian, hilangnya ruang terbuka, perusakan terhadap flora dan fauna, degradasi terhadap lanskap, situs sejarah dan monumen, penurunan volume air, dan terganggunya kehidupan satwa liar (Kreag, 2001). Menurut Mappi Sammeng (2000:212) dampak positif kegiatan pariwisata yaitu konservasi dan rehabilitasi lingkungan alam dan bangunan bersejarah, serta penataan lingkungan. Dampak negatif kegiatan pariwisata terhadap lingkungan alam terutama disebabkan oleh arus wisatawan mencapai jumlah yang banyak. Kualitas air dan udara merosot, dan keanekaragaman hayati akan menurun akibat terdesak oleh pengunjung yang semakin meningkat.

\subsection{Pengelolaan}

Pengelolaan merupakan upaya terpadu untuk melindungi, mengembangkan, dan memanfaatkan warisan budaya melalui kebijakan perencanaan, pelaksanaan, dan pengawasan. Pengelolaan pada dasarnya merupakan aspek manajemen dari pelestarian. Tujuan yang menjiwai pengelolaan adalah memberikan manfaat bagi kesejahteraan rakyat (Rahardjo, 2013). Hal yang serupa juga diungkapkan oleh Pitana (2009). Pengelolaan pariwisata haruslah mengacu pada prinsip-prinsip pengelolaan yang menekankan nilai-nilai kelestarian lingkungan alam, komunitas, dan nilai sosial yang memungkinkan wisatawan menikmati kegiatan wisata serta bermanfaat bagi kesejahteraan komunitas lokal. Beberapa ahli menekankan pentingnya integrasi aspek ekonomi, sosial budaya, dan lingkungan dalam pengelolaan pariwisata (Dowling dan Fennel, 2003:7).

Tujuan dari pengelolaan atau manajemen pariwisata menurut Richardson dan Fluker (2004) adalah untuk menyeimbangkan pertumbuhan dan pendapatan ekonomi melalui pelayanan kepada wisatawan serta perlindungan terhadap lingkungan dan pelestarian keragaman budaya. Oleh karena itu, diperlukan keterlibatan semua pemangku kepentingan di bidang pariwisata untuk mengintegrasikan kerangka pengelolaan pariwisata. Pemangku kepentingan yang dimaksud, yaitu (1) staf dari industri pariwisata, (2) konsumen, (3), investor dan developer, (4) pemerhati dan penggiat lingkungan, (5) pemerhati dan penggiat warisan dan pelestari budaya, (6) masyarakat tuan rumah, (7) pemerintah, dan (8) pelaku ekonomi lokal dan nasional. Prinsip dari penyelenggaraan pengelolaan kepariwisataan yang baik pada intinya adalah adanya koordinasi dan sinkronisasi program antar pemangku kepentingan yang ada serta pelibatan partisipasi aktif yang sinergis (terpadu dan saling menguatkan) antara pihak pemerintah, swasta/industri pariwisata dan masyarakat setempat yang terkait (Sunaryo, 2013:77). Dalam kaitan dengan pariwisata berkelanjutan, Sunaryo (2013:77-78) menyebutkan bahwa secara teoritis pola manajemen dari penyelenggaraan pembangunan kepariwisataan yang berlanjut dan berwawasan lingkungan akan dapat dengan mudah dikenali melalui berbagai ciri penyelenggaraan yang berbasis pada prinsip-prinsip yaitu partisipasi masyarakat terkait, keterlibatan segenap pemangku kepentingan, kemitraan kepemilikan lokal, pemanfaatan sumber daya secara berlanjut, mengakomodasikan aspirasi masyarakat, 
daya dukung lingkungan, monitor dan evaluasi program, akuntabilitas lingkungan, pelatihan pada masyarakat terkait, dan promosi serta advokasi nilai budaya kelokalan

\subsection{Warisan Budaya}

Warisan budaya adalah sesuatu yang dipresentasikan ulang yang berhubungan dengan masa lalu dan memiliki nilai khusus atau signifikan sebagai sebagai kekayaan atau warisan. Warisan budaya dapat berupa sesuatu yang tangible (seperti bangunan, artifak, dan situs), dan intangible (perilaku, aksi dan perbuatan) dari masa lalu yang diinterpretasikan, dinilai, dan dipertimbangkan karena memiliki nilai penting sehingga perlu dilindungi (Ardika, 2015).

Secara garis besar ada dua pandangan tentang makna warisan budaya bagi para pemangku kepentingan (stakeholders), yaitu pandangan pelestarian dan pandangan pengembangan. Pandangan pertama melihat warisan budaya sebagai pusaka yang harus dijaga kelestariannya, dan sangat membatasi segala upaya pemanfaatan yang dapat mengakibatkan kerusakan atau yang membawa potensi untuk mengurangi masa hidup warisan budaya tersebut. Pandangan kedua melihat warisan budaya sebagai pusaka yang akan memiliki arti bila dapat memberi manfaat bagi kebutuhan manusia masa kini, terutama sebagai sumber pemenuhan kebutuhan ekonomi (Rahardjo, 2010). Konflik kedua pandangan tersebut, dinyatakan oleh Ashworth (1997:174) sebagai situasi yang di dalamnya mengandung sifat kontradiktif karena pandangan pelestarian memberi fokus pada upaya stabilisasi sedangkan pandangan pengembangan memberi fokus pada perubahan. Gerakan pelestarian dianggap memperlambat langkah pengembangan dan upaya pengembangan dianggap merusak warisan budaya.

\section{METODE PENELITIAN}

Teknik pengumpulan data yang dipergunakan yaitu observasi dan wawancara. Observasi dilakukan untuk memperoleh gambaran mengenai situasi dan kondisi yang terjadi di lokasi penelitian. Penulis mengaitkan informasi yang diperoleh dengan permasalahan dan tujuan dari penelitian saat melakukan observasi.

Teknik wawancara yang digunakan adalah wawancara mendalam (indepth interview) yaitu wawancara dengan informan yang dianggap memiliki informasi, pengetahuan dan wawasan yang luas terhadap objek penelitian. Wawancara mendalam dilakukan dengan Kepala Desa, Bendesa Adat, Pekaseh, Kelian Dusun, Kelian Tempek, Manajemen Operasional Daya Tarik Wisata Jatiluwih. Pengumpulan data juga menggunakan teknik wawancara terpimpin yakni mengumpulkan data untuk mendapatkan informasi secara langsung dengan mengajukan pertanyaan-pertanyaan kepada para informan berdasarkan pedoman wawancara yang sudah dipersiapkan terlebih dahulu. Wawancara terpimpin dilakukan dengan pengusaha pariwisata dan masyarakat.

\section{PEMBAHASAN}

Dampak pengelolaan Warisan Budaya Dunia Subak Jatiluwih sebagai daya tarik wisata terhadap lingkungan hidup ditinjau dari aspek lingkungan abiotik (air, tanah, udara), kebersihan lingkungan (sanitasi), estetika lingkungan, lingkungan biotik (flora dan fauna). Indikator-indikator dampak pengelolaan Warisan Budaya Dunia Subak Jatiluwih sebagai daya tarik 
wisata terhadap lingkungan hidup dikutip dari Hartanto (1997), Adnyana dan Suarna (2007).

\subsection{Lingkungan Abiotik (Air, Tanah, Udara)}

Mata pencaharian masyarakat Desa Jatiluwih selain dari pertanian juga bersumber dari perkebunan, peternakan, dan usaha-usaha lain. Hampir di setiap rumah tangga memiliki ternak babi, ada juga yang memelihara babi dalam jumlah yang banyak. Peternakan ayam juga banyak dimiliki oleh masyarakat lokal, bahkan terdapat peternakan ayam yang berlokasi di jalur trekking. Meningkatnya perkembangan penduduk dan banyaknya masyarakat yang memiliki peternakan (ayam dan babi) berimplikasi terhadap menurunnya kualitas air. Masyarakat lokal khususnya yang memiliki peternakan ayam dan babi, sebagian memanfaatkan limbahnya untuk pupuk, namun sisanya dialirkan begitu saja ke saluran pembuangan, hal ini dapat mencemari air (sungai dan selokan), juga dapat mencemari tanah. Pencemaran air dan tanah diakibatkan oleh adanya peternakan yang dimiliki masyarakat. Pemilik peternakan tidak memiliki pengolahan limbah mendukung pernyataan Subadra (2006), hal ini dapat berdampak terhadap kualitas air selokan dan sungai. Limbah yang dialirkan ke selokan atau sungai apabila dibiarkan terus-menerus dapat mencemari lahan pertanian dan mempengaruhi lingkungan pariwisata.

Masyarakat Jatiluwih dalam memenuhi air untuk dikonsumsi, memperoleh dari sumber mata air yang kemudian dialirkan melalui pipa ke masing-masing rumah tangga. Air yang dikonsumsi berasal dari sumber mata air di pegunungan, kualitasnya masih bagus.
Pernah ada wisatawan Jepang yang melakukan tes terhadap kualitas air dengan membawa alat tes langsung dari Jepang. Diperoleh hasil tes bahwa nilai TSS (Total Suspended Solid) sebesar 40-60 mg/l". Pengukuran kualitas air tersebut hanya menggunakan parameter Total Suspended Solid (TSS). Dalam pengukuran kualitas air, parameter lain yang juga dipergunakan antara lain pH, suhu, Total Disolved Solid (TDS), Total Phospat, Fecal Coli, Coliform, dan parameter lainnya. Dinas Lingkungan Hidup Kabupaten Tabanan tahun 2018 melakukan pemantauan pada lima sungai di Kabupaten Tabanan meliputi Sungai Yeh Abe, Sungai Yeh Ho, Sungai Yeh Nu, Sungai Yeh Panahan, dan Sungai Yeh Empas. Pemantauan kualitas air sungai dilakukan pada 11 parameter kualitas air yang telah disesuaikan dengan beberapa parameter yang dipersyaratkan sesuai baku mutu air kelas II berdasarkan Peraturan Gubernur Bali Nomor 16 Tahun 2016. Berdasarkan hasil perhitungan status mutu air menggunakan metode Indeks Pencemaran (IP) diketahui bahwa Sungai Yeh Ho pada bagian hulu dan tengah tergolong dalam kategori cemar sedang, dan pada bagian hilir tergolong dalam kategori cemar berat (Dinas Lingkungan Hidup Kabupaten Tabanan, 2018). Sungai Yeh Ho merupakan salah satu sungai yang mengaliri Wilayah Desa Jatiluwih dan sebagai sumber air irigasi bagi Subak Jatiluwih.

Irigasi untuk lahan persawahan yang terdapat di Desa Jatiluwih bersumber dari sungai yang melintasi wilayah desa. Berdasarkan wawancara dengan warga subak, debit air masih besar bahkan lebih dari cukup karena saluran irigasi sudah bagus. Masyarakat Desa Jatiluwih masih menjaga kelestarian wilayah hutan dan keberadaan hutan bambu yang berfungsi 
sebagai penampung air sehingga ketersediaan air untuk pertanian dan memenuhi kebutuhan masyarakat tetap terjaga. Penurunan debit air terjadi di beberapa tempat tergantung lokasi lahan pertanian. Lahan sawah yang lokasinya agak jauh dari aliran sungai pada musim kemarau terkadang mengalami penurunan debit air. Penurunan debit air juga disebabkan oleh perkembangan penduduk, yang berimplikasi pada semakin luasnya lahan perkebunan dan perumahan.

Pengelolaan daya darik wisata mempengaruhi kualitas air, sesuai dengan pernyataan Sharma dan Raina (2014), Adnyana dan Suarna (2007), dan Mappi Sammeng (2000) bahwa pengelolaan pariwisata berdampak terhadap penurunan sumber daya air dan pencemaran air. Sesuai dengan pernyataan Dinas Lingkungan Hidup Kabupaten Tabanan (2018) kegiatan-kegiatan yang dilakukan oleh masyarakat seperti kegiatan domestik, pariwisata, pertanian, industri, perdagangan, dan transportasi telah menyebabkan tekanan terhadap sumber daya lingkungan diantaranya yaitu menurunnya kualitas air.

Selain pencemaran air dan tanah, polusi udara juga merupakan permasalahan lingkungan yang mempengaruhi kualitas lingkungan. Pada saat musim panen, petani umumnya membakar batang tanaman padi yang tersisa. Asap yang ditimbulkan dari pembakaran menimbulkan bau dan mencemari udara di sekitar areal persawahan khususnya lahan sawah yang berada dekat kawasan daya tarik wisata maupun dekat jalur trekking. Pencemaran udara disebabkan juga oleh truk pengangkut kotoran ternak yang melintasi jalur terasering sawah yang dijadikan daya tarik wisata. Warga masyarakat yang memiliki peternakan menjual kotoran yang dihasilkan dari peternakan. Penjualan kotoran ternak ke wilayah Senganan, Penebel dan sekitarnya dalam pengangkutannya melintasi jalan di depan daya tarik wisata.

Terbatasnya lahan parkir yang tersedia seringkali menjadi kendala dalam pengelolaan Daya Tarik Wisata Jatiluwih. Untuk mengatasi masalah ini, pada tahun 2016 dibangun Gong Jatiluwih Restaurant yang ditujukan selain untuk menyediakan fasilitas makan dan minum bagi wisatawan juga untuk menyediakan tempat parkir kendaraan. Fasilitas parkir yang ada selain diperuntukkan bagi wisatawan yang ingin menikmati makan siang maupun sekedar menikmati pemandangan terasering persawahan. Fasilitas parkir dapat menampung sekitar 20 kendaraan. Gong Jatiluwih Restaurant juga berada di lokasi yang sangat strategis, berada di seberang pos pengecekan tiket masuk wisatawan yang datang dari arah Desa Senganan, dan merupakan pintu masuk jalur trekking sebelah utara. Posisi restoran yang berada di lokasi yang tinggi, membuat wisatawan dengan mudah dapat melihat luasnya hamparan persawahan. Pembangunan Gong Jatiluwih Restaurant menimbulkan pro kontra di kalangan masyarakat Desa Jatiluwih karena dibangun pada lahan persawahan yang masih produktif, mendukung pernyataan Kreag (2001) dampak negatif pariwisata terhadap lingkungan yaitu hilangnya bentang alam dan tanah pertanian.

\subsection{Kebersihan Lingkungan (Sanitasi)}

Kebersihan lingkungan menjadi faktor penting dalam pengelolaan Daya Tarik Wisata Jatiluwih. Lingkungan yang bersih dapat memberikan kenyamanan dan mempengaruhi kesehatan. Manajemen Operasional Daya Tarik Wisata Jatiluwih 
melakukan berbagai upaya untuk menjaga kebersihan lingkungan. Sebelum dibentuknya Manajemen Operasional Daya Tarik Wisata Jatiluwih, limbah padat (sampah) yang dihasilkan dari usaha warung makan, restoran, dan homestay dikelola sendiri oleh masing-masing pemilik usaha. Pemilik usaha menampung sampah yang dihasilkan dari usaha mereka, kemudian membuangnya ke tempat penampungan sampah dan ada juga yang membuangnya ke lahan kosong milik pribadi.

Setelah dibentuk Manajemen Operasional Daya Tarik Wisata Jatiluwih, berdasarkan Keputusan Ketua Umum Badan Pengelola Daya Tarik Wisata Jatiluwih Nomor 02 Tahun 2014, pemilik usaha warung makan dan restoran dikenakan iuran kebersihan sebesar $\mathrm{Rp}$. 5.000 per bulan. Sampah dari usaha warung makan dan restoran dikumpulkan oleh petugas kebersihan dari Manajemen Operasional Daya Tarik Wisata Jatiluwih, selanjutnya dibuang ke Tempat Pengolahan Sampah (TPS) yang berada di perbatasan Dusun Kesambahan. Sampah rumah tangga dari masyarakat Desa Jatiluwih dikelola sendiri oleh masing-masing warga. Warga yang memiliki lahan kosong (tegalan/teba) memanfaatkannya sebagai tempat pembuangan sampah, warga yang lainnya mengumpulkan sampah di pekarangan rumah kemudian dibakar, namun ada juga warga yang membuang sampah ke sungai atau saluran air. Kemudian sejak tahun 2015 para pemilik usaha warung makan dikenakan biaya kebersihan sebesar Rp. 50.000 sampai 100.000 , sedangkan untuk usaha restoran dikenakan iuran sebesar Rp. 200.000 .

Untuk mengatasi permasalahan sampah, sejak tahun 2015 pihak Desa Pekraman bekerjasama dengan Manajemen
Operasional Daya Tarik Wisata Jatiluwih merancang pendirian tempat pembuangan sampah yang kemudian diberi nama TPS 3R. Pada tanggal 19 Januari 2018 TPS 3R yang berlokasi di Dusun Kesambahan Kelod diresmikan oleh Bupati Tabanan. Keberadaan TPS 3R berfungsi sebagai bank sampah Desa Jatiluwih untuk pengolahan sampah dari rumah tangga, restoran, warung makan, homestay dan usaha lainnya. Setiap pagi petugas bagian kebersihan Manajemen Operasional Daya Tarik Wisata mengumpulkan sampah dan mengangkutnya ke TPS 3R untuk dipilah. Namun pada saat hari raya dan musim kegiatan adat dimana volume sampah meningkat menyebabkan sampah yang dikumpulkan tidak dapat ditangani seluruhnya sehingga dibawa ke Tempat Penampungan Akhir yang berada di Desa Soka.

Selain pengolahan limbah padat (sampah), pengelolaan limbah cair juga merupakan faktor penting untuk menjaga kebersihan lingkungan. Pada awal dibentuknya Manajemen Operasional Daya Tarik Wisata Jatiluwih pada tahun 2013, limbah cair yang dihasilkan dari usahausaha pariwisata belum dikelola. Pemilik warung makan dan restoran membuang limbah cair dari usaha yang dikelola ke saluran air sehingga hal ini menimbulkan pencemaran terhadap tanah dan air yang berimplikasi terhadap lahan pertanian. Semenjak tahun 2016 Manajemen Operasional Daya Tarik Wisata Jatiluwih mengharuskan bagi pemilik usaha-usaha pariwisata baik pengusaha restoran, warung makan maupun homestay dan villa untuk membuat penampungan limbah cair. Masing-masing pemilik usaha menyediakan dua buah bak penampungan limbah (septic tank). Sebelum limbah cair dialirkan ke bak penampungan, terlebih 
dahulu dipisahkan antara limbah cair berupa minyak dengan sisa makanan. Limbah cair kemudian dialirkan ke bak penampungan, sedangkan sisa makanan ditampung pada tempat terpisah yang kemudian dimanfaatkan untuk pakan ternak babi. Dampak dari pengelolaan daya tarik wisata dapat menimbulkan limbah (Kreag, 2001) yang dihasilkan dari usaha pariwisata. Melalui manajemen pengelolaan limbah yang baik dapat meminimalisasi dampak negatif yang ditimbulkan terhadap lingkungan.

Selain pengelolaan limbah padat dan cair, untuk menjaga kebersihan lingkungan, Manajemen Operasional juga menyediakan tempat sampah di sekitar Daya Tarik Wisata Jatiluwih yaitu di jalur trekking dan di Tugu Penetapan Subak Jatiluwih sebagai bagian dari Warisan Budaya Dunia. Tempat sampah yang disediakan dipisahkan antara sampah organik dengan sampah non organik. Disamping itu, karyawan divisi kebersihan dan pertamanan juga melakukan pemotongan rumput setiap sebulan sekali di sepanjang jalur trekking dan sepanjang jalan menuju lokasi daya tarik wisata.

\subsection{Estetika Lingkungan}

Lingkungan yang bersih, asri, dan indah dapat membuat wisatawan merasa nyaman selama berkunjung ke suatu destinasi. Keasrian dan keindahan lingkungan tercermin dari penataan sarana dan prasarana pariwisata. Penataan lingkungan harus disesuaikan dengan estetika lingkungan. Menurut Sugandhy (1999) estetika lingkungan adalah hasil dari persepsi dan sikap manusia terhadap lingkungannya. Estetika lingkungan terwujud dalam bentuk (1) terjaganya arsitektural bangunan serta kesesuaian dengan lingkungan sekitar atau bentang alam serta ketinggian bangunan; terbinanya lanscapping dengan adanya pepohonan di setiap lingkungan perumahan dan kawasan kegiatan sesuai dengan ekosistem wilayah; (3) lingkungan pemukiman yang bebas dari bau; (4) lingkungan pemukiman yang bebas dari gangguan kebisingan; (5) lingkungan pemukiman yang bebas dari gangguan getaran; dan (6) lingkungan pemukiman yang bebas dari gangguan radiasi.

Arsitektur bangunan yang berada di areal Daya Tarik Wisata Jatiluwih mencerminkan bangunan tradisional Bali. Usaha-usaha pariwisata seperti warung makan, restoran, dan homestay secara umum berbentuk bangunan tradisional Bali. Bahan-bahan bangunan yang dipakai menggunakan bahan-bahan lokal seperti atap bangunan dari jerami dan ijuk, pemakaian kayu dan bambu pada sebagian sisi bangunan, bahkan ada beberapa fasilitas warung makan dan restoran yang menyediakan gazebo model Bali seperti yang terdapat pada Warung Dea, Warung Krisna, dan Warung Wayan. Fasilitas pariwisata dibangun mengikuti bentang alam Desa Jatiluwih yang berundak-undak, sesuai dengan pernyataan Kreag (2001) dampak positif pariwisata dapat memperbaiki penampilan suatu daerah (visual dan estetika).

Usaha warung makan, restoran, dan homestay yang berlokasi di sebelah sisi Barat dari terasering sawah yang dijadikan daya tarik wisata, posisinya lebih tinggi dari sisi Timur sehingga bangunannya disesuaikan dengan ketinggian lahan. Terdapat beberapa usaha yang berada di pinggir jalan namun dibuat bertingkat, posisinya hanya berjarak sekitar 100-meter dari pinggir jalan. Adanya bangunan bertingkat tersebut memang tidak menghalangi pandangan apabila dilihat dari sisi belakang, tetapi jika dilihat dari dari sisi 
depan mengurangi estetika karena hanya berjarak beberapa meter dari sisi jalan raya.

Penyediaan berbagai fasilitas dalam pengelolaan Daya Tarik Wisata ditujukan untuk memenuhi kebutuhan dan memberikan kepuasan bagi wisatawan selama berkunjung. Selain penyediaan fasilitas makan dan minum, penataan jalur trekking juga dilakukan sebagai upaya untuk memberikan kemudahan bagi wisatawan dalam menikmati keindahan terasering persawahan. Terdapat tiga pintu masuk jalur trekking yaitu dari sisi Selatan yang berada dekat Tugu Penetapan Subak Jatiluwih sebagai bagian dari Warisan Budaya Dunia, dari sisi Utara yang berada di pos pengecekan tiket yang berada di depan Gong Restaurant Jatiluwih, dan dari Dusun Gunungsari Desa yang lokasinya berada di seberang Warung Krisna. Jalur trekking selain diperuntukkan bagi wisatawan juga berfungsi sebagai jalan subak yang dimanfaatkan untuk menunjang aktivitas petani. Petani memanfaatkannya sebagai jalan untuk menuju ke sawah masing-masing maupun untuk mengangkut hasil panen.

Sebelum penetapan Subak Jatiluwih sebagai bagian dari Warisan Budaya Dunia, dilakukan pengerasan dengan semen pada jalan sepanjang jalur trekking agar tidak licin pada saat hujan. Pengerasan dilakukan pada dua sisi agar bisa dilalui mobil, di tengahnya dibiarkan berupa tanah. Setelah dibentuknya Manajemen Operasional Daya Tarik Wisata Jatiluwih, dilakukan penataan jalur trekking karena beberapa bagian jalan mengalami kerusakan. Pada jalur trekking sisi utara, saat ini dilakukan pembetonan sepanjang satu kilometer, di bagian atasnya dibuatkan ornamen berbentuk ikan. Pembetonan jalur trekking memang membuat pondasi jalan lebih kuat, namun dari sisi estetika kurang sesuai karena daya tarik yang ditawarkan berupa alam sehingga kurang sesuai dengan lingkungan sekitar.

Lokasi Daya Tarik Wisata Jatiluwih merupakan wilayah yang terbuka, masyarakat umum bebas melewatinya apabila melakukan perjalanan dari arah Senganan maupun Wangaya Gede. Lokasinya yang strategis memudahkan wisatawan untuk mencapai daya tarik wisata karena berada di pinggir jalan raya, namun wisatawan juga merasa kurang nyaman. Masyarakat Desa Jatiluwih banyak yang memiliki peternakan ayam, pada saat mengangkut kotoran ayam untuk dijual ke daerah lain, kendaraannya melewati Daya Tarik Wisata Jatiluwih. Hal ini menimbulkan bau yang tidak sedap.

\subsection{Lingkungan Biotik (Flora danFauna)}

Lingkungan sekitar wilayah Desa Jatiluwih masih terjaga keasriannya. Berbagai tumbuh-tumbuhan khas daerah pegunungan tumbuh dengan suburnya seperti kopi, coklat, kelapa, nangka, bambu, pohon cempaka, dan yang lainnya. Wilayah Desa Jatiluwih berada di daerah pegunungan dengan tekstur tanah yang subur. Hijaunya pepohonan yang tumbuh di sekitar wilayah desa membuat suasana semakin sejuk. Berbagai pepohonan tumbuh subur di areal pemukiman penduduk, perkebunan dan areal hutan Desa Jatiluwih. Masyarakat lokal menjaga kelestarian hutan karena berfungsi sebagai daerah resapan dan penampung air, selain itu juga terdapat awig-awig agar masyarakat lokal tidak sembarangan menebang pohon dan merusak hutan. Masyarakat Jatiluwih tidak diperbolehkan menebang pohon nangka dan tidak boleh menggunakan kayu nangka untuk bangunan, karena pohon nangka sangat berjasa bagi leluhur masyarakat setempat. 
Pohon nangka masih dihormati oleh masyarakat lokal hingga saat ini. Pada areal pertanian di sepanjang pematang sawah, rumput gajah dan rerumputan tumbuh dengan subur. Pohon kelapa juga tumbuh pada beberapa areal persawahan menambah keindahan panorama sekitar.

Manajemen Operasional Daya Tarik Wisata Jatiluwih memasang beberapa papan yang yang bertuliskan himbauan bagi wisawatan agar tidak memetik atau merusak tanaman padi. Upaya ini dilakukan agar wisatawan menjaga dan menghormati keberadaan padi sebagai tanaman yang dihormati oleh warga subak. Wisatawan yang menikmati panorama terasering persawahan mematuhi larangan tersebut, banyak wisatawan yang terpukau melihat tanaman padi lokal dengan tinggi mencapai 1,5-meter dan wisatawan sangat antusias untuk mengabadikannya.

Binatang yang hidup di sekitar wilayah Desa Jatiluwih juga dijaga kelestariannya. Kijang merupakan binatang langka yang hidup di Hutan Desa Jatiluwih, keberadaannya sangat dijaga, tidak diperbolehkan untuk berburu kijang kecuali untuk upacara persembahan pada saat pujawali di Pura Puseh Pengulu. Burungburung yang ada di sekitar areal persawahan, komunitasnya masih banyak. Untuk menjaga populasi burung, Pemerintah Desa Jatiluwih menetapkan peraturan berupa larangan menembak burung dan tidak boleh sembarangan mencari anakan burung untuk tetap menjaga kelestarian habitatnya, namun komitmen masyarakat masih kurang. Burung bangau yang merupakan burung khas daerah pertanian masih banyak dijumpai, namun populasinya mulai mengalami penurunan. Menurut warga subak, burung bangau mudah dijumpai ketika musim membajak sawah karena ketika membajak sawah, cacing yang menjadi makanan burung lebih gampang didapatkan.

Fauna lain yang hidup di sawah seperti belut, keong sawah (kakul), klipes, dan cacing tanah populasinya mulai mengalami penurunan akibat pemakaian pupuk non organik dalam pengolahan lahan pertanian. Hal ini mempengaruhi keberadaan burung, dimana burung memerlukan makanan sedangkan makanannya terkontaminasi oleh penggunaan pupuk. Menurunnya populasi burung yang ada di Desa Jatiluwih diakibatkan oleh kurangnya kesadaran masyarakat dan akibat pemakaian pupuk non organik. Belut yang merupakan binatang khas yang hidup di sawah masih banyak ditemukan, belut dari Desa Jatiluwih rasanya berbeda dibandingkan dengan daerah lain.

Keberadaan flora dan fauna yang terdapat di Desa Jatiluwih tetap dijaga kelestariannya sesuai dengan pernyataan Sumberartha (2014) dalam awig-awig Subak Jatiluwih mengandung nilai kearifan lokal pelestarian lingkungan biotik. Pernyataan tersebut didukung oleh Muriawan (2014) Desa Jatiluwih memiliki beragam mitos yang dipercaya oleh masyarakat, dan tidak berani untuk melanggar/menentangnya karena diyakini dapat menimbulkan berbagai musibah, keberadaan mitos ini sangat berperan dalam menjaga kelestarian lingkungan alam. Hal ini menentang pernyataan Kreag (2001) dan Mappi Sammeng (2000) terjadi perusakan flora dan fauna dengan adanya pengembangan pariwisata.

\section{PENUTUP}

Pengelolaan Warisan Budaya Subak Jatiluwih sebagai daya tarik wisata menimbulkan berbagai dampak terhadap 
lingkungan. Pengelolaan pariwisata berdampak terhadap penurunan sumber daya air dan pencemaran air. Selain pencemaran air dan tanah, polusi udara juga merupakan permasalahan lingkungan yang mempengaruhi kualitas lingkungan. Pembangunan fasilitas pariwisata yang tidak sesuai dengan tata ruang berdampak negatif terhadap lingkungan yaitu hilangnya bentang alam dan tanah pertanian. Pengelolaan daya tarik wisata juga berdampak positif terhadap lingkungan. Kebersihan lingkungan semakin dijaga dimana terdapat bank sampah berupa TPS 3R, terdapat penampungan limbah cair pada usahausaha pariwisata. Fasilitas pariwisata dibangun mengikuti bentang alam Desa Jatiluwih yang berundak-undak yang berdampak terhadap penampilan wilayah (visual dan estetika). Masyarakat lokal menjaga kelestarian hutan karena berfungsi sebagai daerah resapan dan penampung air, selain itu juga terdapat awig-awig agar masyarakat lokal tidak sembarangan menebang pohon dan merusak hutan. Binatang yang hidup di sekitar wilayah Desa Jatiluwih juga dijaga kelestariannya. Keberadaan flora dan fauna yang terdapat di Desa Jatiluwih tetap dijaga kelestariannya, dalam awig-awig Subak Jatiluwih mengandung nilai kearifan lokal pelestarian lingkungan biotik. Desa Jatiluwih memiliki beragam mitos yang dipercaya oleh masyarakat, keberadaan mitos ini sangat berperan dalam menjaga kelestarian lingkungan alam.

Mengkaji dampak dari pengelolaan daya tarik wisata dapat dijadikan sebagai bagian dari kegiatan monitoring dan evaluasi. Melalui pengkajian dampak positif dan negatif, dapat diketahui perubahan-perubahan yang terjadi sehingga dapat dijadikan sebagai pedoman dalam perencanaan program kerja dari pengelolaan daya tarik wisata yang berkelanjutan.

\section{DAFTAR PUSTAKA}

Adnyana, I W.S., dan Suarna, I W. (2007). "Permasalahan dan Kerusakan Lingkungan Hidup". dalam Raka Dalem, A.A.G., Wardi, I N., Suarna, I W., dan Adnyana, I W. S. Kearifan Lokal dalam Pengelolaan Lingkungan Hidup. Denpasar: UPT Penerbit Universitas Udayana bekerjasama dengan Pusat Penelitian Lingkungan Hidup UNUD.

Antara, M., Wijaya, G.N.K., dan Windia, W. (2017). Ekowisata Subak Jatiluwih Tabanan, Bali. Denpasar: Pelawa Sari.

Ardika, I W. (2015). Warisan Budaya Perspektif Masa Kini. Denpasar: Udayana University Press.

Ashworth, G. J. (1997)." Elements of Planning and Managing Heritage Site". dalam W. Nuryanti (ed). Tourism and Heritage Management. Yogyakarta: Gadjah Mada University Press.

Dinas Lingkungan Hidup Kabupaten Tabanan. (2018). Laporan Analisa Kualitas Air dan Udara. Tabanan.

Dowling, R.K., dan Fennel, D.A. (2003). "The Context of Ecotourim Policy and Planning". dalam Ross K. Dowling dan David A. Fennel (eds). Ecotourism Policy and Planning. Cambridge: CABI Publishing.

Hartanto, F.M. (1997). "Menjelang Pembangunan Pariwisata yang Berkelanjutan: Perspektif Perencanaan Kebijaksanaan”. dalam Myra P. Gunawan (ed). Prosiding Pelatihan dan Lokakarya Perencanaan Pariwisata Berkelanjutan. Bandung: ITB.

Kreag, G. (2001). The Impacts of Tourism. Minnesota: University of Minnesota Press. 
Mappisammeng, Andi. (2000). Cakrawala Pariwisata. Jakarta: Kementerian Negara Pariwisata dan Kesenian.

Muriawan. (2014). "Penerapan Mitos Sebagai Sarana Efektif Implementasi Tri Hita Karana di Desa Jatiluwih Menuju Pariwisata Berkelanjutan". Jurnal Perhotelan dan Pariwisata. 4 (1): 14-47.

Pitana, I G. (1999). Pelangi Pariwisata Bali. Denpasar: Bali Post.

Rahardjo, S. (2013). Beberapa Permasalahan Pelestarian Kawasan Cagar Budaya dan Strategi Solusinya. Jurnal Konservasi Cagar Budaya Borobudur. 7(2): 4-17.

Richardson, J.I., dan Fluker, M. (2004). Understanding and Managing Tourism. Australia: Pearson Education.

Sharma, A., dan Raina, A.K. (2014). Enviromental Impacts of Tourism in Katra Town. International Journal of Innovative Research in Science, Engineering and Technology. 3(6): 13740-13746.

Subadra, I N., dan Nadra, N.M. (2006). Dampak Ekonomi, Sosial Budaya dan Lingkungan Pengembangan Desa Wisata di Jatiluwih Tabanan. Jurnal Manajemen Pariwisata. 5 (1): 46-64.

Sugandhy, A. (1999). Penataan Ruang dalam Pengelolaan Lingkungan Hidup. Jakarta: Gramedia Pustaka Utama.

Sumberartha, I W. (2014). Kajian tentang Peranan Nilai-nilai Kearifan Lokal Subak dalam Pelestarian Lingkungan dan Tantangan Eksistensinya: Studi kasus di Subak Jatiluwih, Kecamatan Penebel, Kabupaten Tabanan, Provinsi Bali. Tesis. Yogyakarta: Universitas Gadjah Mada.

Sunaryo, B. (2013). Kebijakan Pembangunan Destinasi Pariwisata:
Konsep dan Aplikasinya di Indonesia. Yogyakarta: Gava Media.

Undang-undang Republik Indonesia Nomor 32 Tahun 2009. Perlindungan dan Pengelolaan Lingkungan Hidup. Jakarta 